\title{
Early Postnatal Astroglial Cells Produce Multilineage Precursors and Neural Stem Cells In Vivo
}

\author{
Yosif M. Ganat, ${ }^{1 \star}$ John Silbereis, ${ }^{1 \star}$ Clinton Cave, ${ }^{1}$ Hai Ngu, ${ }^{1}$ George M. Anderson, ${ }^{1}$ Yasushi Ohkubo, ${ }^{1}$ Laura R. Ment, ${ }^{2}$ \\ and Flora M. Vaccarino ${ }^{1,3}$ \\ ${ }^{1}$ Child Study Center and ${ }^{2}$ Departments of Pediatrics and Neurology and ${ }^{3}$ Neurobiology, Yale University Medical School, New Haven, Connecticut 06520
}

To identify the fates that astroglial cells can attain in the postnatal brain, we generated mice carrying an inducible Cre recombinase $\left(C r e-\mathrm{ER}^{\mathrm{T} 2}\right.$ ) controlled by the human GFAP promoter ( $h$ GFAP). In mice carrying the GCE (hGFAP-Cre-ER ${ }^{\mathrm{T} 2}$ ) transgene, OHT (4-hydroxytamoxifen) injections induced Cre recombination in astroglial cells at postnatal day 5 and allowed us to permanently tag these cells with reporter genes. Three days after recombination, reporter-tagged cells were quiescent astroglial cells that expressed the stem cell marker LeX in the subventricular zone (SVZ) and dentate gyrus (DG). After 2- 4 weeks, the tagged GFAP lineage included proliferating progenitors expressing the neuronal marker Dcx (Doublecortin) in the SVZ and the DG. After 4 weeks, the GFAP lineage generated mature neurons in the olfactory bulb (OB), DG, and, strikingly, also in the cerebral cortex. A major portion of all neurons in the DG and OB born at the end of the first postnatal week were generated from $\mathrm{GFAP}^{+}$cells. In addition to neurons, mature oligodendrocytes and astrocytes populating the cerebral cortex and white matter were also the progeny of $\mathrm{GFAP}^{+}$astroglial ancestors. Thus, genetic fate mapping of postnatal $\mathrm{GFAP}^{+}$cells reveals that they seed the postnatal brain with neural progenitors/stem cells that in turn give rise to neural precursors and their mature neuronal and oligodendrocytic progeny in many CNS regions, including the cerebral cortex.

Key words: astrocyte; glial fibrillary acidic protein; Cre recombinase; lineage; neural stem cells; LeX

\section{Introduction}

Multipotential and self-renewing neural progenitors/stem cells (NSCs) that reside in the adult subventricular zone (SVZ) and hippocampal dentate gyrus (DG), express glial fibrillary acidic protein (GFAP) and exhibit some phenotypic properties of astrocytes (Doetsch et al., 1999; Seri et al., 2001). Similarly, embryonic multipotential neural progenitors have active Gfap and Blbp (brain lipid binding protein) gene promoters (Malatesta et al., 2000, 2003; Anthony et al., 2004; Casper and McCarthy, 2006) and express some astroglial markers, including Vimentin, the astrocyte-specific glutamate-aspartate transporter (GLAST), and the RC1 and RC2 intermediate filament epitopes (Misson et al., 1988; Kriegstein and Gotz, 2003). These embryonic multipotent progenitors, also called "radial glia," span the entire cortical wall and generate through asymmetric cell divisions neural precursors that eventually differentiate into neurons and migrate to the cerebral cortex (Noctor et al., 2001; Englund et al., 2005; Gal et al., 2006). After the completion of cortical neurogenesis, radial glia

\footnotetext{
Received Sept. 23, 2005; revised July 6, 2006; accepted July 7, 2006.

This work was supported in part by National Institutes of Health Grants NS 35476 and MH067715 and the National Alliance for Research on Schizophrenia and Depression. Y.M.G. was the recipient of a National Institute of General Medical Sciences Post-Baccalaureate Research Education Program Scholarship. We thank Drs. Michael Brenner and Albee Messing for the hGFAP promoter fragment; Dr. Pierre Chambon for the CreER ${ }^{\mathrm{T} 2}$ construct; Drs. Nathaniel Heintz, Pasko Rakic, Magdalena Gotz, and Urs Rutishauer for gifts of antibodies; and Joshua Breunig for technical advice.

*Y.M.G. and J.S. contributed equally to this work.

Correspondence should be addressed to Flora M. Vaccarino, Child Study Center, 230 South Frontage Road, New Haven, CT 06520. E-mail: flora.vaccarino@yale.edu.

DOI:10.1523/JNEUROSCI.2532-06.2006

Copyright $\odot 2006$ Society for Neuroscience $\quad$ 0270-6474/06/268609-13\$15.00/0
}

transform into astrocytes by retracting their apical (ventricular) processes and migrating upward toward the cortical plate (Schmechel and Rakic, 1979; Pixley and de Vellis, 1984; Smith et al., 2006).

Given the shared molecular properties between radial glia and adult NSCs, it may not be surprising that the latter originate from radial glial cells (Merkle et al., 2004). However, the point at which the radial glia-NSC lineage diverges from that of parenchymal astrocytes is unclear. It has been shown that young astrocytes, but not adult astrocytes, are pluripotent and can generate neurospheres in vitro, exhibiting NSC-like properties (Laywell et al., 2000). However, in vivo evidence for this hypothetical "astrocytic stem cell" is lacking. For example, retroviral lineage analyses have characterized the generation of olfactory interneurons, cortical astrocytes, and oligodendrocytes from SVZ progenitors (Marshall et al., 2003; Zerlin et al., 2004; Luskin, 1993), but whether GFAP ${ }^{+}$ astroglial "ancestors" can generate these three lineages in the postnatal SVZ has not been established. Previously, exploration of the neurogenic potential of astroglial cells has been hindered by the inability to both identify these cells at defined periods of development and subsequently follow their long-term fate.

We analyzed the lineage of postnatal astroglial cells by using the human GFAP ( $h G F A P$ ) gene promoter to drive the expression of an inducible form of the Cre recombinase in transgenic mice. Cre, the product of Cre (cyclization recombination) gene of bacteriophage $\mathrm{P} 1$, catalyzes the reciprocal recombination of genomic segments that are flanked by loxP sequences (Sauer, 1998). We used a Cre-estrogen receptor $\left(\mathrm{Cre}-\mathrm{ER}^{\mathrm{T} 2}\right)$ fusion protein that is inactive unless it binds to the estrogen analog 4-hydroxytamoxifen (OHT) (Metzger et al., 1995). hGFAP-Cre-ER ${ }^{\mathrm{T} 2}$ 
(GCE) transgenic mice were crossed with two Cre reporter mouse strains, R26R and $\mathrm{Z} / \mathrm{eG}$, that permanently drive the expression of $\beta$-galactosidase ( $\beta$ gal) (Soriano, 1999 ) or the enhanced green fluorescent protein (GFP) (Novak et al., 2000), respectively, in $\mathrm{GFAP}^{+}$cells and all of their progeny. Long-term fate mapping of these cells revealed that they do not remain confined to the astrocyte lineage, but rather can give rise to a large number of neural precursors as well as their mature neuronal and oligodendrocytic progeny in many regions of the postnatal CNS. Furthermore, astroglial cells targeted in the perinatal period give rise to NSCs in the mouse SVZ.

\section{Materials and Methods}

Generation of GCE transgenic mice. A $2.0 \mathrm{~kb}$ EcoRI fragment from the pCreER ${ }^{\mathrm{T} 2}$ vector (Feil et al., 1996; Indra et al., 1999) was inserted into the pGfa vector containing the human GFAP promoter (the gfa2 fragment, extending from bp -2163 to +47 relative to the RNA start site of +1) (Brenner, 1994; Brenner et al., 1994) to obtain the GCE construct. The GCE construct was digested with ApalI and SphI and the resulting 5481 bp DNA fragment was purified and used to generate transgenic mice via pronuclear injection into $\mathrm{C} 57 \mathrm{BL} / 6 \mathrm{~J} \times \mathrm{SJL} / \mathrm{J} \mathrm{F} 2$ one-cell embryos. Founder mice positive for germline transmission were screened for GCE expression by breeding with reporter R26R mice. GCE mice were genotyped by PCR, using primers binding to the Cre 5'-GCAACGAGTGATGAGGTTCGCAAG-3' (forward), and the $\mathrm{ER}^{\mathrm{T} 2} 5^{\prime}$-TCCGCCGCATAACCAGTGAAACAG-3' (reverse), to amplify a $307 \mathrm{bp}$ fragment. PCR was performed using the following conditions: $94^{\circ} \mathrm{C}, 10 \mathrm{~min} ; 74^{\circ} \mathrm{C}, 1 \mathrm{~min} ; 94^{\circ} \mathrm{C}, 1$ $\min ; 58.1^{\circ} \mathrm{C}, 1 \mathrm{~min} ; 72^{\circ} \mathrm{C}, 1 \mathrm{~min}, 34$ cycles.

Characterization of transgene expression. Males with germline expression in the $\mathrm{F}_{1}$ and $\mathrm{F}_{2}$ generations were bred with homozygous R26R females to obtain double transgenic offspring and used for the initial characterization (see Fig. 1). For subsequent experiments, GCE mice were backcrossed to C57BL mice for four to six generations before breeding with either R26R or Z/eG mice (The Jackson Laboratory, Bar Harbor, ME). Z/eG mice were genotyped for the GFP construct with the forward 5'-AAGTTCATCTGCACCACCG-3' and reverse $5^{\prime}$-TGCTCAGGTAGTGGTTGTCG-3' primers to amplify a $475 \mathrm{bp}$ product. Stock solutions of OHT (H-6278; Sigma, St. Louis, MO) were prepared at a concentration of either $10 \mathrm{or} 1 \mathrm{mg} / \mathrm{ml}$ in autoclaved sunflower seed oil. Pups were injected with OHT intraperitoneally at a dosage of $33 \mathrm{mg} / \mathrm{kg}$ body weight.

2-Bromodeoxyuridine birth dating and proliferation assays. For all experiments, 2-bromodeoxyuridine ( $\mathrm{BrdU})(5 \mathrm{mg} / \mathrm{ml}$ in $0.007 \mathrm{~N} \mathrm{HCl} / 0.9 \%$ $\mathrm{NaCl}$; Sigma) was administered intraperitoneally at a dosage of $50 \mu \mathrm{g} / \mathrm{kg}$ body weight. Either a single or two injections spaced $3 \mathrm{~h}$ apart were administered.

Immunohistochemistry and X-gal staining. Mice were perfused with $4 \%$ paraformaldehyde (PFA) and brains were postfixed overnight at $4^{\circ} \mathrm{C}$, except for those used for X-gal staining, which were postfixed for $15 \mathrm{~min}$. Immunostaining was performed in serial cryosections as described previously (Ganat et al., 2002). Sections were blocked in PBS containing
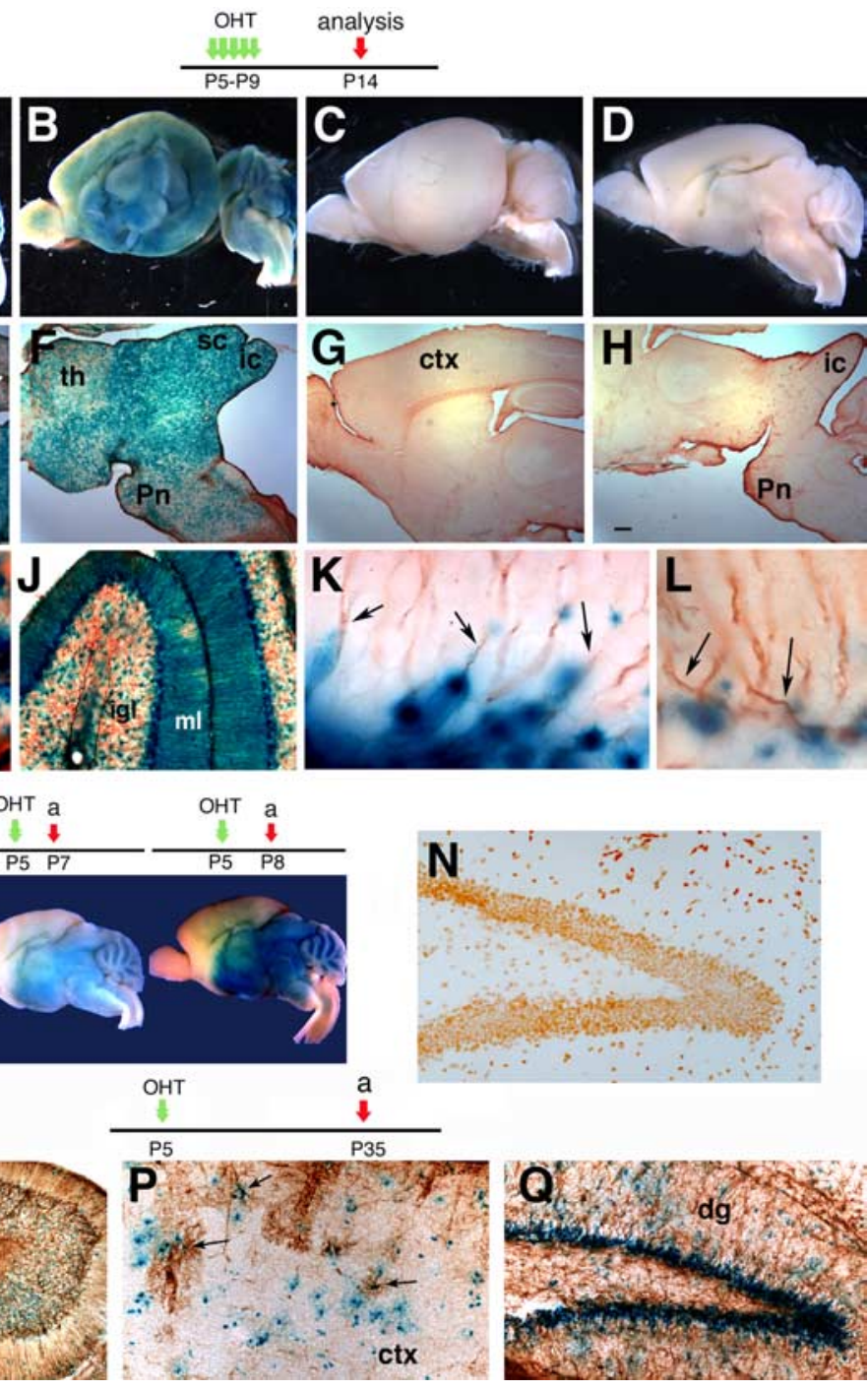

Figure 1. Cre recombination mediated by the GCE transgene is inducible by $0 \mathrm{HT}$ in vivo. $\mathrm{OHT}(33 \mathrm{mg} / \mathrm{kg})$ or sunflower oil vehicle points indicated by the red arrows. All sections show X-gal staining in line 505. A-D, Whole-mount X-gal staining in $\mathrm{GCE}^{+}$/ tamoxifen ${ }^{+}(\boldsymbol{A}, \boldsymbol{B})$ or $\mathrm{GCE}^{+} /$tamoxifen $^{-}(\boldsymbol{C}, \boldsymbol{D})$. $\boldsymbol{E}$ - $\boldsymbol{L}, \mathrm{X}$-gal-stained sections from $\mathrm{GCE}{ }^{+} /$tamoxifen $^{+}(\boldsymbol{E}, \boldsymbol{F}, \boldsymbol{I}-\boldsymbol{L})$ or $\mathrm{GCE}^{+} /$ cerebellum $(\boldsymbol{J}, \boldsymbol{L}) . \boldsymbol{K}$ and $\boldsymbol{L}$ show high magnification views of the DG and the Purkinje layer, respectively. The arrows point to -stained fibers with X-gal ${ }^{+}$cell bodies. $\boldsymbol{M}$, Whole-mount specimens stained for X-gal at different times after two $0 \mathrm{HT}$ 作 analyzed at P35. a, Analysis; ctx, cerebral cortex; th, thalamus; sc, superior colliculus; ic, inferior colliculus; pn, pons; dg, dentate gyrus; h, hilus; igl, internal granular layer; ml, molecular layer. Scale bars: $\boldsymbol{E}-\boldsymbol{H}, 200 \mu \mathrm{m} ; \boldsymbol{I}, \mathbf{N}, \boldsymbol{P}, \boldsymbol{Q}, 12.5 \mu \mathrm{m} ; \boldsymbol{J}, \mathbf{0}, 25 \mu \mathrm{m} ; \boldsymbol{K}, \boldsymbol{L}, 5 \mu \mathrm{m}$.

$0.1 \%$ Tween $20 / 0.2 \%$ Triton (PBS-T) containing $10 \%$ goat serum $(10 \%$ GS/PBS-T) or $10 \%$ donkey serum (10\% DS/PBS-T), and then incubated in primary antibody in 5\% GS/PBS-T or DS/PBS-T. For colocalization experiments involving BrdU and additional markers, the immunocytochemistry was performed in two stages and BrdU immunostaining was performed last. After immunostaining for the other markers, the tissue was postfixed in $2 \%$ PFA for $15 \mathrm{~min}$ at room temperature, followed by incubation for $1 \mathrm{~h}$ in $1.5 \mathrm{~N} \mathrm{HCl}$. The tissue was then washed three times for $10 \mathrm{~min}$ in PBS, and immunostaining for BrdU was then performed in the same manner as described for other antigens. We used the following primary antibodies: NeuN (Chemicon, Temecula, CA), GFAP (Chemicon), S100 $\beta$ (Invitrogen, Eugene, OR), Nestin (Hybridoma Bank, Iowa City, IA), GFP (Invitrogen or Chemicon), $\beta$ gal (Five Prime-Three Prime, Boulder, CO; and Chemicon), Rip (Chemicon), myelin/ oligodendrocyte-specific protein (MOSP) (Dyer et al., 1991), NG2 (Chemicon), Doublecortin (Dcx) (Santa Cruz Biotechnology, Santa 
Cruz, CA), polysialic acid-neural cell adhesion molecule (PSA-NCAM) (gift from Urs Rutishauser, Sloan Kettering Center, NY), BrdU (Accurate Chemicals, Westbury, NY), LeX (BD Biosciences, Mountain View, CA), RC1 and RC2 (Hybridoma Bank), and Vimentin (Sigma). Sections were washed and processed with secondary antibodies of the appropriate species, coupled to Alexa 350, Alexa 488, or Alexa 594 (all from Invitrogen), to fluorescein (Jackson ImmunoResearch, West Grove, PA), to AMCA (7-amino-4-methylcoumarin-3-acetic acid) (Vector Laboratories, Burlingame, CA), or to biotin (Vector Laboratories). For immunoperoxidase detection, the ABC Elite kit (Vector Laboratories) was used as directed. $\beta$ gal activity was detected via incubation in $4 \% \mathrm{X}$-gal solution overnight at $37^{\circ} \mathrm{C}$.

Morphometry, cell counting, and confocal analysis. Unbiased estimates for volumes and cell numbers were obtained using a computer coupled to a Zeiss (Oberkochen, Germany) Axioskope 2 Mot Plus equipped with a motorized stage, running the StereoInvestigator software (MicroBrightField, Colchester, VT). Double immunostaining was visualized by a 594 and $488 \mathrm{~nm}$ double exposure filter. Nuclear profiles were counted in three-dimensional counting frames, using a randomly placed sampling grid of $500 \times 500 \mu \mathrm{m}$ on the cortex and cerebellum, $500 \times 300 \mu \mathrm{m}$ on the olfactory bulb (OB) and hippocampal regions, and $100 \times 100 \mu \mathrm{m}$ on the SVZ. Counting frames $(100 \times 100 \times 6$ or $425 \times 230 \times 6 \mu \mathrm{m}$, depending on the region) were placed in the upper portion of the section ( $1 \mu \mathrm{m}$ below the surface) to avoid variations caused by differential penetration of antibodies. Cells immunoreactive for GFP were only counted if they overlapped a 4',6'-diamidino-2-phenylindole-stained cell nucleus. Confocal analysis was done on an Axioskop Mot II Plus equipped with a HeNe laser (Zeiss). All $z$-stacks were performed through the analysis of $1 \mu \mathrm{m}$ serial sections. $z$-stacks for sections triple stained for BrdU and cellular markers were analyzed and acquired via an ApoTome equipped Axiovert 200M with Axiovision 4.5 software (Zeiss).

4-Hydroxytamoxifen levels in serum. The serum levels of the $Z$ and $E$ isomers of OHT were determined in $20-40 \mu \mathrm{l}$ of mouse serum after the addition of an equal volume of acetonitrile and centrifugation. The supernatant was directly injected $(20 \mu \mathrm{l})$ and the isomers were separated by reverse-phase HPLC using a $25 \times 0.46 \mathrm{~cm}$ Waters Spherosorb $5 \mu \mathrm{m}$ C6 column eluted $\left(0.9 \mathrm{ml} / \mathrm{min}\right.$; column temperature, $\left.35^{\circ} \mathrm{C}\right)$ with a mobile phase of $45 \%$ acetonitrile, $35 \%$ methanol, and $20 \%$ water with $0.1 \%$ triethylamine added. The $Z$ and $E$ isomers eluted at 6.4 and $7.6 \mathrm{~min}$, respectively, and were detected by their native UV absorbance at $260 \mathrm{~nm}$ with detection limits of $\sim 20 \mathrm{ng} / \mathrm{ml}$ serum and coefficients of variation of $<5 \%$.

\section{Results}

\section{Generation of transgenic mice with inducible Cre-ERT2} under the hGFAP promoter (GCE)

The Cre-ER ${ }^{\mathrm{T} 2}$ construct encodes for a fusion protein that, unlike other Cre recombinases, lacks the nuclear localization sequence and only translocates to the nucleus in response to the estrogen analog OHT (Metzger et al., 1995; Feil et al., 1996; Indra et al., 1999). Cre-ER ${ }^{\mathrm{T} 2}$ was placed under the control of a $2.2 \mathrm{~kb}$ region of the hGFAP promoter (Brenner et al., 1994) to obtain the GCE construct. Transgenic mice harboring the GCE construct were bred with the R26R reporter line, and double-transgenic GCE; R26R mice of the $F_{1}$ and $F_{2}$ generations were assessed for LacZ expression in response to five daily OHT injections in the postnatal period as diagramed at the top of Figure 1. All 19 GCE founder lines displayed OHT-specific Cre recombinase activity, as demonstrated by the absence of detectable reporter gene expression without OHT treatment (Fig. $1 A-H$ ). The amount of reporter gene expression varied between lines, yet we consistently found that the strongest X-gal activity was present in the SVZ, DG, cerebellum, mesencephalon, and diencephalon, followed by the cerebral cortex. Cre recombination was enriched in the subgranular zone of the DG and the cerebellar Purkinje layer containing Bergmann glia (Fig. $1 I, J$ ), and in these areas GFAP ${ }^{+}$ astroglial cell processes appeared to extend from lac ${ }^{+}$cell bod-
Table 1. Percentage of reporter ${ }^{+}$cells that express the indicated phenotypic markers (mean \pm SEM) 3 d after recombination

\begin{tabular}{|c|c|c|c|c|c|}
\hline Region & GFAP & $\begin{array}{l}\text { GFAP and } \\
\text { RC1 }\end{array}$ & $D c x$ & NeuN & Rip \\
\hline SVZ & $75.9( \pm 7.0)$ & $79.5( \pm 6.0)$ & $9.4( \pm 1.7)$ & 0 & 0 \\
\hline$O B$ & * & * & $*$ & 0 & 0 \\
\hline Cortex & $61.4( \pm 4.9)$ & $77.0( \pm 1.1)$ & * & 0 & 0 \\
\hline Hippoc. DG & $76.6( \pm 7.7)$ & $92.5( \pm 1.8)$ & ND & 0 & 0 \\
\hline Hippoc. СA & $73.1( \pm 8.5)$ & $100.0( \pm 0)$ & * & 0 & 0 \\
\hline Hippoc. WM & $86.2( \pm 3.6)$ & $95.1( \pm 2.0)$ & * & 0 & 0 \\
\hline CB EGL & * & * & * & 0 & 0 \\
\hline CB PR and IGL & $83.0( \pm 5.8)$ & * & * & 0 & 0 \\
\hline CB ML & $81.8( \pm 7.7)$ & * & * & 0 & 0 \\
\hline CB WM & $87.8( \pm 4.8)$ & * & * & 0 & 0 \\
\hline
\end{tabular}

GCE transgenic mice, crossed with the R26R or the Z/EG reporter lines, were injected with $\mathrm{OHT}$ at $\mathrm{P5}$ and analyzed at $\mathrm{P} 8$ ( $N$, between 3 and 6 animals per group). These phenotypes are not meant to be inclusive of every cell and the percentages do not always add to $100 \%$.

Hippoc., Hippocampus; CB, cerebellum; CA, pyramidal layer; EGL, external granular layer; PR, Purkinje cell layer; IGL, internal granular layer. Reporter ${ }^{+}$cells were sampled throughout the region of interest by unbiased sampling methods using the optical fractionator method. ND, Not determined.

* Marker not expressed or reporter ${ }^{+}$cell density too small to obtain a statistically reliable number.

ies (Fig. $1 K, L$ ). Based on the extent of $\beta$ gal expression, we selected two lines (GCE505 and GCE516) for subsequent experiments.

To estimate the timing of Cre recombination after OHT treatment, we measured levels of the $Z$ and $E$ isomers of OHT in mouse serum at different times after a single $\mathrm{OHT}$ intraperitoneal injection (33 mg/kg; $Z / E$ ratio, 2.6). At 1, 6, 12, 24, 48, and $72 \mathrm{~h}$ postinjection, serum levels of the more abundant $Z$ isomer were $4.21,0.84,0.26,0.24,0.14$, and $0.09 \mu \mathrm{g} / \mathrm{ml}$, and the levels of the $E$ isomer form were $1.59,0.32,0.09,0.17,<0.02$, and $<0.02 \mu \mathrm{g} / \mathrm{ml}$, respectively. Total ( $Z$ plus $E$ ) OHT serum levels observed $12 \mathrm{~h}$ postinjection were $6 \%$ of the levels seen at $1 \mathrm{~h}$. After two OHT injections at postnatal day 5 (P5) spaced by $4 \mathrm{~h}$ in the GCE;R26R double transgenic mice, $\beta$ gal enzymatic activity was faintly detectable at $24 \mathrm{~h}$ and clearly enhanced 2 and $3 \mathrm{~d}$ after OHT delivery (Fig. $1 M$ ). The same injection protocol elicited long-term LacZ reporter induction after $30 \mathrm{~d}$ with similar pattern and intensity as that elicited by the five consecutive injections, whereas no LacZ activity was detected without OHT treatment (Fig. 1, compare $N$, $O-Q)$. Combined with the pharmacokinetic data above, these data suggest that tamoxifen-dependent nuclear translocation of Cre and reporter gene induction are likely to occur within the first 12-24 h after OHT treatment, in agreement with results obtained in another tamoxifen inducible line (Leone et al., 2003). After this period, no further Cre recombination is likely to occur, but reporter genes remain constitutively expressed in targeted cells and their progeny.

\section{The GCE transgene targets Cre recombination to astroglial cells in vivo}

To determine the type(s) of cells that are marked by the GCE transgene, GCE transgenic mice also carrying the R26R or Z/eG reporter genes were analyzed shortly after Cre recombination. Three days after OHT treatment at embryonic day 13.5 (E13.5) to E14.5, $\beta$ gal was strongly expressed not only throughout the ventricular zone (VZ) and SVZ of the dorsal telencephalon, but also in scattered cells within the intermediate zone (IZ) and the cortical plate (CP) of the cerebral cortical anlage (supplemental Fig. $1 A-C$, available at www.jneurosci.org as supplemental material). In the $\mathrm{VZ}$ and SVZ, $\beta \mathrm{gal}^{+}$cells were double-labeled with antibodies to the progenitor protein Nestin as well as the radial glial marker RC2 (supplemental Fig. $1 D$, available at www.jneurosci.org 
as supplemental material). In contrast, in the IZ and CP, $\beta \mathrm{gal}^{+}$cells were unlabeled by these markers, but they were positive for neuronal $\beta$ III-tubulin immunoreactivity (supplemental Fig. $1 F, G$, available at www.

jneurosci.org as supplemental material). These cortical neurons likely inherited reporter gene expression from their radial glial progenitors, because radial glia rapidly generate cortical neurons via asymmetric divisions at this time in development (Noctor et al., 2001). These data suggest that GCE can drive Cre activity to typical radial glial cells during embryogenesis.

We next examined the cell types that were marked by GCE-induced Cre recombination in the early postnatal period, when radial glial cells mature into astrocytes (Pixley and de Vellis, 1984; Gadisseux et al., 1992). GCE mice that were mated with the $\mathrm{R} 26 \mathrm{R}$ or the $\mathrm{Z} / \mathrm{eG}$ reporter lines were given two OHT injections at P5, and reporter ${ }^{+}$cells, identified by $\beta$ gal and GFP immunoreactivity, were phenotyped $3 \mathrm{~d}$ later using a variety of lineage markers. A comparison between the two reporter lines revealed that the $\mathrm{Z} / \mathrm{eG}$ line revealed $\sim 10 \%$ of the number of Cre-recombined cells when compared with the R26R line (supplemental Table 1, available at www. jneurosci.org as supplemental material). This was apparently not a consequence of transcriptional silencing of the reporter gene, because we observed high basal $\beta$ gal gene expression in Z/eG mice (supplemental Fig. 2, available at www. jneurosci.org as supplemental material), but rather may be attributable to a lower efficiency of Cre recombination in this line. Nevertheless, the percentage of reporter ${ }^{+}$cells that colocalized the different phenotypic markers was similar in both R26R and Z/eG mice, and therefore counts obtained in these two reporter lines were combined (Table 1).

Three days after recombination, the majority of reporter ${ }^{+}$cells expressed GFAP and RC1, a monoclonal antibody that binds to an intermediate filament epitope expressed by immature astrocytes (Edwards et al., 1990; Liu et al., 2002) (Figs. 2, 3; supplemental Fig. 3, available at www.jneurosci.org as supplemental material). Reporter ${ }^{+}$cells also expressed other astrocytic markers at this time, such as Glast, nestin, glutamine synthetase, and S100 $\beta$ (supplemental Fig. $3 A-I$, available at www.jneurosci.org as supplemental material LAST (data not shown). The proportion of reporter ${ }^{+}$cells that coexpressed GFAP immunoreactivity at the P8 time

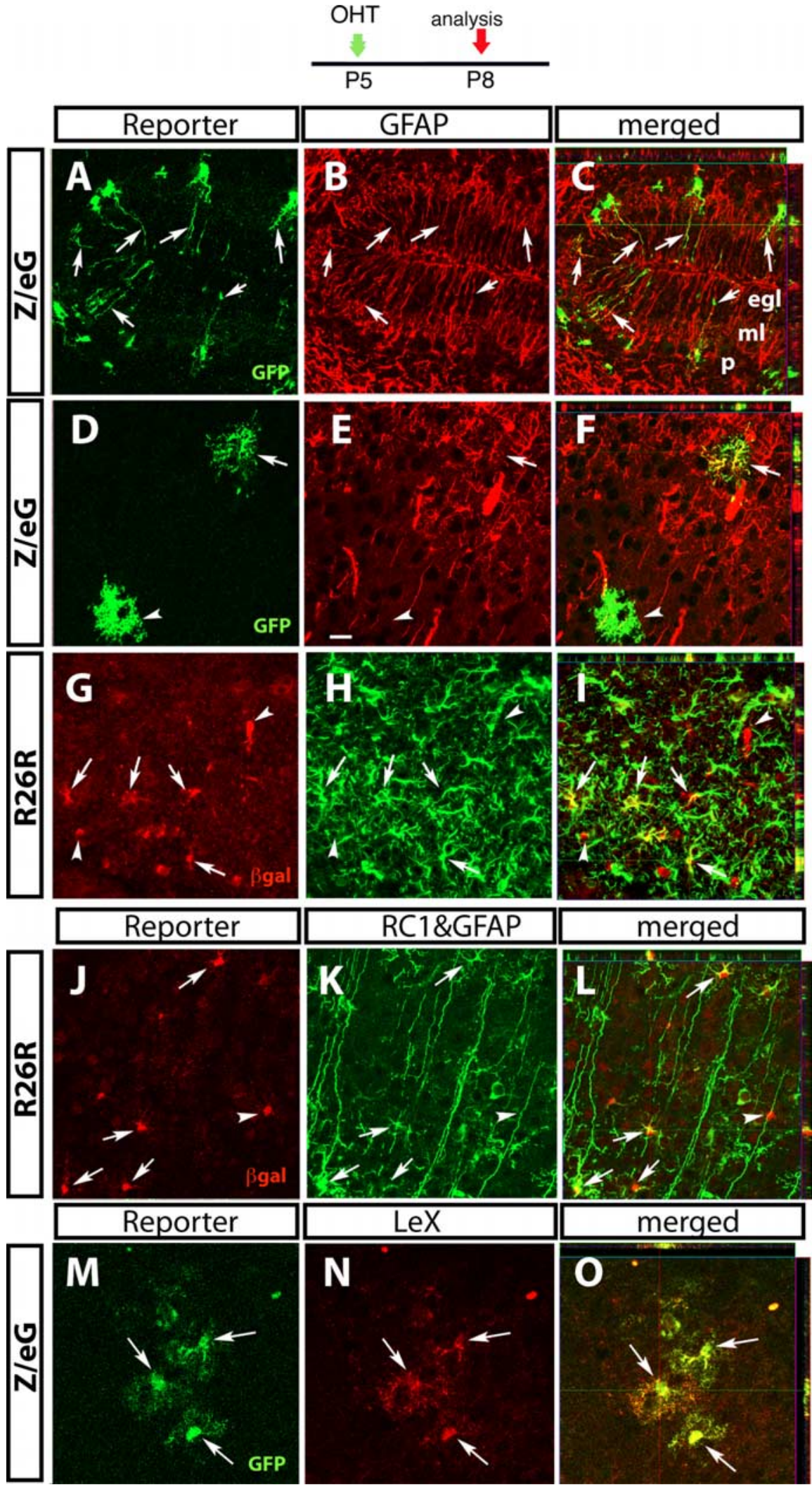

Figure 2. Mature and immature astrocytes are targeted by (re recombination in the cortex and cerebellum at P5. GCE mice double-transgenic for the R26R or the Z/eG reporter lines (as indicated on the left side) were injected with $0 \mathrm{HT}$ at P5. Three days after recombination, reporter ${ }^{+}$cells visualized by $\beta$ gal or GFP immunostaining were characterized by double staining with astroglial markers as indicated, followed by confocal microscopy. Cerebellum $(\boldsymbol{A}-\boldsymbol{C})$ and cerebral cortex $(\boldsymbol{D}-\mathbf{O}) . A, D, G, J, M$, Single optical sections immunostained with the reporter gene product. $B, E, H, K, N$, The same sections immunostained for the astroglial markers. $\boldsymbol{C}, \boldsymbol{F}, \boldsymbol{I}, \boldsymbol{L}, \mathbf{O}$, Merged images with Z-plane analyses obtained from stacks of confocal sections. The arrows point to double-immunostained cells; the arrowheads point to reporter ${ }^{+}$cells negative for the markers. egl, External granular layer; $\mathrm{ml}$, molecular layer; $p$, Purkinje cell layer. Scale bars: $\boldsymbol{A}-\boldsymbol{L}, 20 \mu \mathrm{m} ; \boldsymbol{M}-\mathbf{0}, 12.5 \mu \mathrm{m}$. 


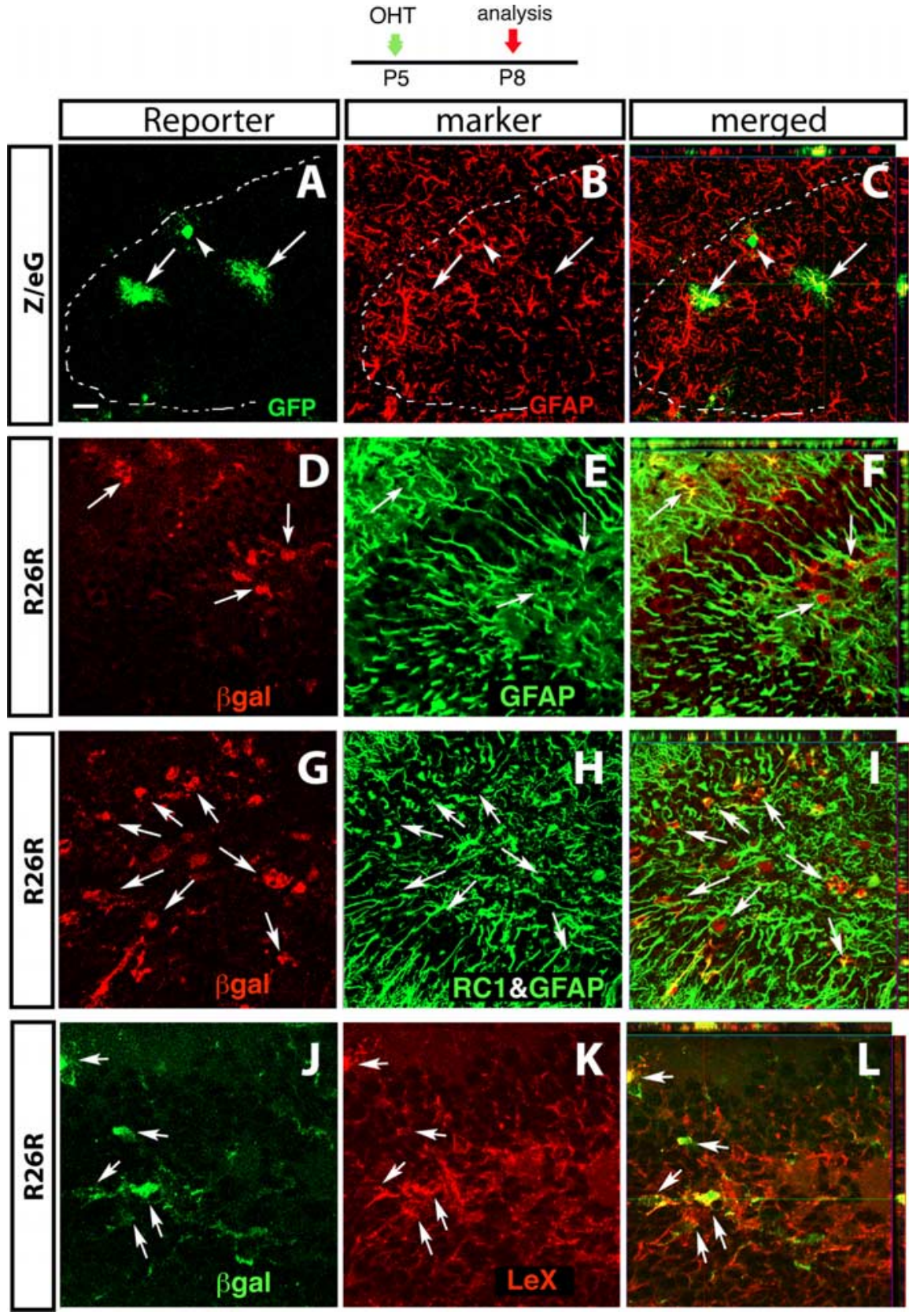

Figure 3. Mature and immature astrocytes are targeted by Cre recombination in the dentate gyrus at P5. GCE mice doubletransgenic for the R26R or the Z/eG reporter lines (as indicated on the left side) were injected with OHT at P5. Three days after recombination, reporter ${ }^{+}$cells were characterized by double immunostaining with astroglial markers (as indicated) followed by confocal microscopy. All images show the dentate gyrus. $A, D, G, J$, Single optical sections immunostained with the reporter gene product. $\boldsymbol{B}, \boldsymbol{E}, \boldsymbol{H}, \boldsymbol{K}$, The same sections immunostained for astroglial markers as indicated. $\boldsymbol{C}, \boldsymbol{F}, \boldsymbol{I}, \boldsymbol{L}$, Merged images with Z-plane analyses obtained from stacks of confocal sections. The dashed white lines in $\boldsymbol{A}-\mathbf{C}$ outline the hilus (h). The arrows point to doubleimmunostained cells; the arrowheads point to reporter ${ }^{+}$cells negative for the markers. Scale bars: $A-I, 20 \mu \mathrm{m} ; J-L, 12.5 \mu \mathrm{m}$.

In the cerebellum, $82-88 \%$ of report$\mathrm{er}^{+}$cells expressed GFAP (Table 1). Reporter $^{+}$Bergmann glial cells coexpressing GFAP, nestin, or $S 100 \beta$ were noted at the interface between the molecular layer $(\mathrm{ML})$ and internal granular layer (IGL) (Figs. 1 J, 2A-C; supplemental Fig. 3A-C, available at www.jneurosci.org as supplemental material). These cells were negative for LeX (data not shown), a carbohydrate surface antigen expressed by pluripotent embryonic stem cells and by NSCs and other astroglia in the SVZ of adult mice (Capela and Temple, 2002). Fewer $\beta$ gal cells were observed in the ML and IGL (Fig. 2A-C; supplemental Fig. 3A-C, available at www.jneurosci.org as supplemental material).

In the cerebral cortex, $61 \%$ of report$\mathrm{er}^{+}$cells were GFAP immunoreactive (Table 1, Fig. $2 D-I)$. To ascertain whether reporter ${ }^{+}$cells that were negative for GFAP were immature cells of the astroglial lineage, we immunostained sections with the monoclonal antibodies Nestin and RC1, which recognize immature astrocytes. When used in combination, RC1 and GFAP antibodies labeled most of the reporter ${ }^{+}$cells in cortex $(77.0 \% \pm 1.1)(\mathrm{Ta}-$ ble 1). Some were typical multipolar astrocytes (supplemental Fig. 3D-F, available at www.jneurosci.org as supplemental material) and others were transitional astroglia extending one process to the pial membrane (Fig. $2 J-L$ ). Virtually all reporter ${ }^{+}$ cells in the P8 cerebral cortex expressed LeX throughout their cell bodies and processes (Fig. $2 \mathrm{M}-\mathrm{O}$ ). We did not detect reporter expression in classic radial glial cells spanning the cerebral cortical wall.

In the hippocampus, multipolar reporter ${ }^{+} / \mathrm{GFAP}^{+}$and $\mathrm{S} 100 \beta^{+}$cells were located in the hilus, the molecular and pyramidal layers, and the WM (Fig. $3 A-C$; supplemental Fig. 3G-I, arrows; available at www.jneurosci.org as supplemental material). Additionally, in the DG, unipolar $\mathrm{Bgal}^{+}$cells were located in the subgranular zone and extended long GFAP-labeled processes in the blades of the DG (Fig. 3D$F$ ). Approximately $75 \%$ of these reporter cells coexpressed GFAP and close to $100 \%$

point was $>80 \%$ in white matter (WM), although it was more variable within different gray matter regions (Table 1) (see below). In contrast, neither the $\beta$ gal- nor GFP-labeled cells colocalized the NeuN epitope, which is present in postmitotic neurons, or Rip and Ng2 immunoreactivities, which characterize, respectively, oligodendrocytes and their precursors (supplemental Fig. $4 A-I$, available at www.jneurosci.org as supplemental material). Among over 1900 ßgal- or GFP-labeled cells examined at P8, we did not find a single cell double-labeled by NeuN or Rip, confirming that GCE-targeted cells do not belong to neuronal or oligodendrocyte lineages (Table 1). were double-labeled by a combination of GFAP and RC1 (Fig. $3 G-I$, Table 1 ) or by LeX antibodies (Fig. $3 J-L$ ). Hence, in the hippocampus, as in the cerebral cortex, a portion of reporter cells were too immature to express detectable GFAP immunoreactivity but were labeled by RC1 and LeX.

We used a variety of cell type-specific markers to characterize GCE expression in the SVZ, including $S 100 \beta^{+}$to label ependymal cells (Gregg and Weiss, 2003), GFAP and RC1 to label astroglia, and PSA-NCAM and Dcx as markers for neuronal progenitors (Doetsch et al., 1999; Liu et al., 2002). At P8, 3 d after recombination, the ependymal layer was largely negative for re- 
porter gene expression, although an occasional $\mathrm{S} 100 \beta^{+}$ependymal cell was $\beta$ gal positive (Fig. $4 A$, arrow). Within the SVZ/ subependymal zone, $79.5 \%$ of reporter ${ }^{+}$ cells were labeled by GFAP and RC1 antibodies (Table 1, Fig. 4B-D). In addition, $\sim 9 \%$ expressed the neural precursor marker Dcx (see Fig. 7G,N, Table 1). The remaining $10 \%$ had a small, round soma and few or no processes, and were not double-labeled by $S 100 \beta$, nestin, or GLAST antibodies (Fig. 4A-D, arrowheads) (data not shown). The only epitope that was expressed by virtually all report$\mathrm{er}^{+}$cells in the SVZ was the carbohydrate antigen LeX (Fig. 4E, F, arrows). Interestingly, LeX immunoreactivity characterized reporter ${ }^{+}$cells in the cerebral cortex, DG, and SVZ, but not reporter ${ }^{+}$astrocytes in the adjacent striatal parenchyma (Fig. $4 F$, arrowhead) or in the cerebellum.

In summary, reporter ${ }^{+}$cells manifested phenotypes of mature or immature astroglia, characterized by GFAP, $\mathrm{S} 100 \beta$, and $\mathrm{RC} 1$ expression within $72 \mathrm{~h}$ of Cre recombination. However, $\sim 10-15 \%$ of reporter ${ }^{+}$cells in the SVZ and cerebral cortex did not exhibit immunoreactivity to any antibody except LeX. These data taken in concert suggest that GCE expressing cells labeled at P5 comprise astroglia at various stages of maturity and may include a stem cell or progenitor population.

\section{GCE-targeted astroglial cells generate neurons, astrocytes, and oligodendrocytes}

The relative density and regional localization of reporter ${ }^{+}$cells remained the same when GCE;R26R and GCE;Z/eG doubletransgenic pups were injected with OHT at P5 and analyzed at P35 (supplemental Ta-

ble 1, available at www.jneurosci.org as supplemental material), suggesting no major change in the sensitivity of detection of R26R- or Z/eG-expressing cells. However, the population of reporter ${ }^{+}$cells now consisted of neurons, astrocytes, and oligodendrocytes, suggesting major changes in the long-term fate of the astroglial cells that underwent Cre recombination at P5. For example, in the hippocampal WM, reporter ${ }^{+}$cells comprised not only $\mathrm{GFAP}^{+}$astrocytes but also Rip ${ }^{+}$oligodendrocytes, whereas $90 \%$ of reporter ${ }^{+}$cells within the DG expressed the neuronal antigen NeuN (Table 2; Fig. 5A, arrowheads; $B, D$, arrows). Some neurons relatively close to the subgranular layer had aspiny and relatively unbranched dendrites, whereas those deeper into the DG had spiny dendrites of greater length and complexity and extended axons into the hilus (Fig. 5A,B), a morphology typical of mature granule neurons (Esposito et al., 2005). Immunostaining for Dcx and PSA-NCAM, proteins transiently expressed in neuronal progenitors, demonstrated the presence of a large number of reporter ${ }^{+}$neural precursors and immature young neurons (Figs. 5F, 7L). Approximately $10 \%$ of reporter ${ }^{+}$cells in the DG expressed GFAP; these cells were located in the subgranular zone and also expressed LeX (Fig. 5A, C,E, Table 2). This small popu-
Table 2. Percentage of reporter ${ }^{+}$cells that express the indicated phenotypic markers (mean \pm SEM) $30 \mathrm{~d}$ after recombination

\begin{tabular}{lllll}
\hline Region & GFAP & DCx & NeuN & Rip \\
\hline SVZ & $62.2( \pm 4.7)$ & $39.1( \pm 2.9)$ & 0 & 0 \\
OB & $26.8( \pm 2.9)$ & $*$ & $59.0( \pm 5.1)$ & $2.8( \pm 0.7)$ \\
Cortex & $57.9( \pm 4.1)$ & $*$ & $0.3( \pm 0.02)$ & $14.1( \pm 4.3)$ \\
Hippoc. DG & $9.9( \pm 1.1)$ & ND & $89.9( \pm 2.1)$ & 0 \\
Hippoc. CA & $68.1( \pm 7.0)$ & $*$ & $<0.1 \%$ & 0 \\
Hippoc. WM & $80.1( \pm 5.5)$ & $*$ & $<0.1 \%$ & $4.1( \pm 0.8)$ \\
CB ML & $74.0( \pm 3.6)$ & $*$ & $<0.1 \%$ & 0 \\
CB WM & $68.0( \pm 7.1)$ & $*$ & 0 & $12.4( \pm 5.3)$ \\
\hline
\end{tabular}

GCE transgenic mice, crossed with the R26R or the Z/EG reporter lines, were injected with $\mathrm{OHT}$ at $\mathrm{P} 5$ and analyzed at P35 ( $N$, between 3 and 6 animals per group). These phenotypes are not meant to be inclusive of every cell and the percentages do not always add to $100 \%$. Abbreviations are as in Table 1 . Reporter ${ }^{+}$cells were sampled throughout the region of interest by unbiased sampling methods using the optical fractionator method. ND, Not determined. * Marker not expressed.

lation of reporter ${ }^{+} / \mathrm{LeX}^{+}$astroglia in the subgranular zone may be a local population of NSCs that generates the reporter ${ }^{+}$neuronal progenitors, although neuronal progenitors may also reach the DG from an external source.

In the cerebral cortex at P35, 58\% of reporter ${ }^{+}$cells were 


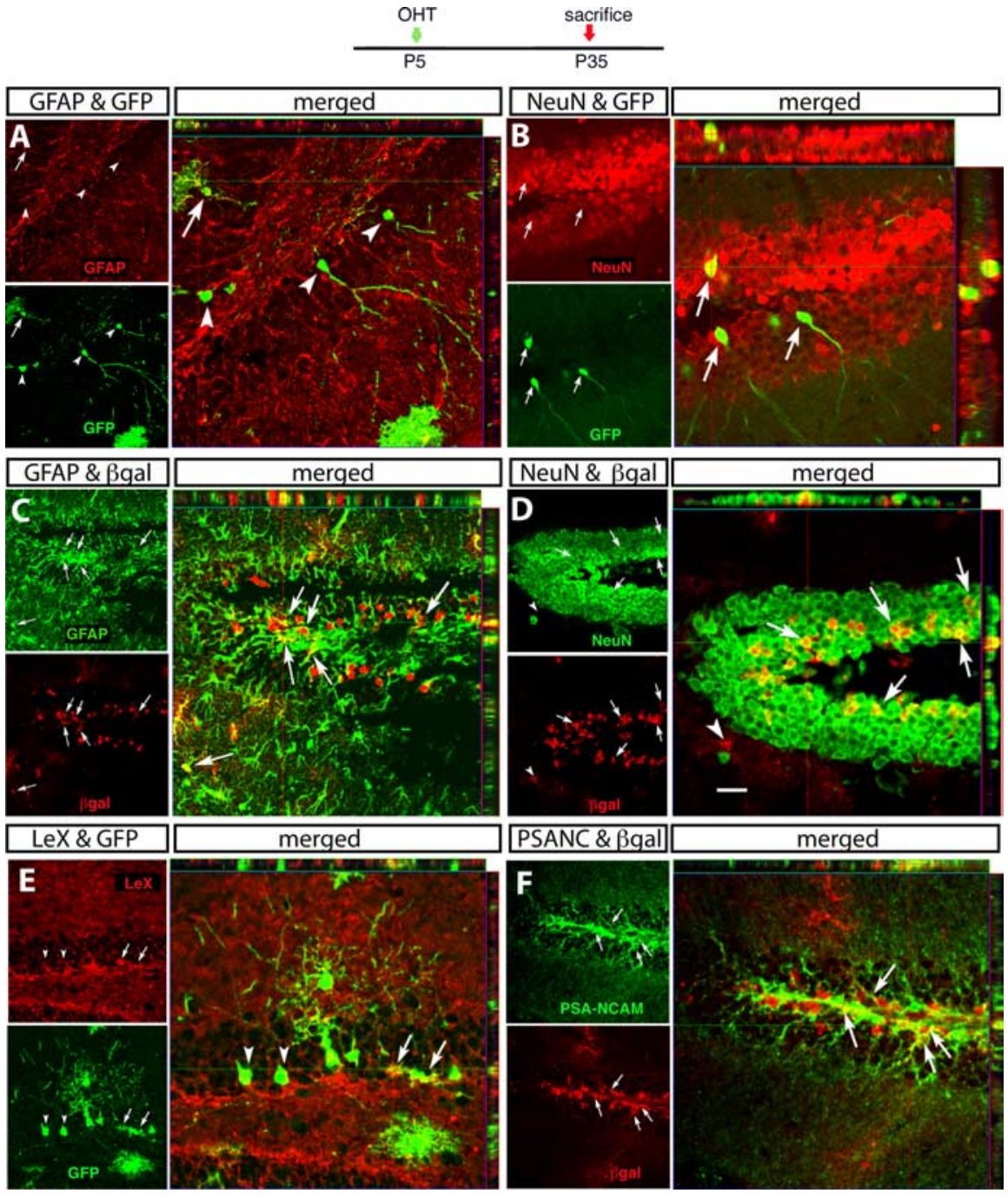

Figure 5. Long-term fate of targeted astroglial cells in the dentate gyrus. Immunocytochemical characterization of reporterexpressing cells 1 month after recombination. Each set of three confocal images illustrates the following: on the upper left, a sagittal section immunostained with $\operatorname{GFAP}(\boldsymbol{A}, \boldsymbol{C}), \operatorname{NeuN}(\boldsymbol{B}, \boldsymbol{D})$, LeX $(\boldsymbol{E})$, or PSA-NCAM $(\boldsymbol{F})$; underneath, the same section immunostained for the reporter gene; and on the right side, the merged images with the confocal Z-stack analysis. Reporter ${ }^{+}$cells $^{-}$ coexpressing the markers are indicated by arrows, and reporter ${ }^{+}$cells negative for the markers are indicated by arrowheads. Scale bars: $\boldsymbol{A}, \boldsymbol{D}, \boldsymbol{E}, \boldsymbol{F}, 20 \mu \mathrm{m} ; \boldsymbol{B}, 12.5 \mu \mathrm{m} ; \boldsymbol{C}, 32 \mu \mathrm{m}$.

GFAP $^{+}$astrocytes (Fig. 6A, Table 2). These cells had an extensive degree of arborization compared with those found at P8, which is consistent with a higher degree of maturity [compare supplemental Fig. $3 F$ (available at www.jneurosci.org as supplemental material) with Fig. $6 \mathrm{~A}$ ]. In addition, $\sim 14 \%$ of $\beta$ gal $^{+}$cortical cells were double-stained with the oligodendrocyte markers Rip and MOSP, particularly in the infragranular cortical layers (Fig. 6C; supplemental Fig. 3M-O, available at www.jneurosci.org as supplemental material; Table 2). Thus, a relatively large proportion of GCE-targeted cells acquired an oligodendrocytic fate in the cortex. We also found that a small proportion of cortical report$\mathrm{er}^{+}$cells were double-stained with the neuronal antigens NeuN and $\mathrm{Hu}$ (Table 2, Fig. $6 \mathrm{D}, E$ ). A portion of these $\beta \mathrm{gal}^{+}$neurons expressed the GABA synthesizing enzyme glutamic acid decarboxylase (GAD67), suggesting that they were GABAergic (Fig. $6 F$ ). Others had pyramidal morphology but did not express glutamatergic markers, possibly because of their immaturity (data not shown). Together, these data suggest that astroglial cells in the postnatal period can either remain in the astrocyte lineage or differentiate into hippocampal granule neurons, cortical neurons, or oligodendrocytes.

\section{NSCs in the postnatal SVZ are the progeny of postnatal GFAP ${ }^{+}$cells} In adults, NSCs are thought to be relatively quiescent $\mathrm{GFAP}^{+} / \mathrm{LeX}^{+}$astroglial cells that divide infrequently to self-reproduce and to give rise to proliferative transitamplifying cells and neural progenitors dividing with a $13 \mathrm{~h}$ cell cycle (Morshead et al., 1994; Doetsch et al., 1997; Capela and Temple, 2002; Zheng et al., 2004). The neuronal progenitors migrate to the $\mathrm{OB}$ (Lois and Alvarez-Buylla, 1993; Luskin, 1993), the DG (Seaberg and van der Kooy, 2002; Aguirre et al., 2004; Bull and Bartlett, 2005), and, in young animals, also the neocortex (Fagel et al., 2006). Hence, reporter-tagged DG granule neurons and cortical neurons at P35 could have been the progeny of NSCs that were expressing GFAP at P5. To substantiate this, we assessed whether reporter ${ }^{+}$cells gave rise to proliferating neuronal progenitors. When mice were given two BrdU injections at the same time of OHT treatment at P5 and analyzed $3 \mathrm{~d}$ later, only $\sim 10 \%$ of report$\mathrm{er}^{+}$cells were labeled, indicating that GCE-targeted cells were relatively quiescent (Fig. 7A,M). Furthermore, at this time point, only $9 \%$ of tagged cells expressed the neuronal progenitor marker Dcx in the SVZ and apparently none in the DG (Fig. 7G,J,N). This confirms that the GCE transgene targets Cre recombinase activity to astroglial cells and not to transient amplifying precursors or neuronal progenitors. To assess whether the transition to dividing precursor cells occurred later in this lineage, mice that were OHTinjected at P5 were examined at P18 and $\mathrm{P} 38$, which is 13 and $33 \mathrm{~d}$ after OHT induction, respectively. At $\mathrm{P} 18,33 \%$ of reporter ${ }^{+}$cells in the SVZ expressed Dcx (Fig. $7 \mathrm{H}, \mathrm{N}$ ) and PSA-NCAM (data not shown); furthermore, the same proportion was mitotically active, as judged by the incorporation of BrdU administered $3 \mathrm{~d}$ before analysis (Fig. $7 \mathrm{~B}, \mathrm{M}$ ). In 38 -d-old mice, slightly higher percentages of reporter ${ }^{+}$cells (40\%) expressed Dcx in the SVZ (Fig. $7 \mathrm{I}, \mathrm{N})$ and the same proportion incorporated a $\mathrm{BrdU}^{+}$pulse administered $3 \mathrm{~d}$ before analysis (Fig. 7M). Triple staining demonstrated that reporter ${ }^{+}$cells that expressed Dcx also colocalized BrdU (Fig. 7C-F), suggesting that the tagged astroglial lineage generates the transit-amplifying and the $\mathrm{Dcx}^{+}$neuronal progenitors. In addition, some reporter ${ }^{+}$cells expressed the surface antigen NG2 (supplemental Fig. $4 K$, available at www.jneurosci.org as supplemental material) and the transcription factor Mash1 (Fig. 8D), both of which mark bipotential neuron/oligodendrocyte progenitors (Aguirre and Gallo, 2004; Parras et al., 2004). Together, the data demonstrate that, in the SVZ, there is ongoing generation of proliferative neuronal as well as glial precursors from descendants of $\mathrm{GFAP}^{+}$cells tagged at P5. 
To further understand whether these neural progenitors derived from tagged NSCs, we assessed whether reporter ${ }^{+}$cells also expressed markers for putative NSCs in the young adult SVZ. Unbiased counting revealed that $62 \%$ of reporter ${ }^{+}$cells in the SVZ were GFAP ${ }^{+}$at P35 (Table 2). These cells had a small, round soma and few short processes, resembling the branched "B" cells described by Doetsch et al. (1999) (Fig. 8A, arrows). The majority of reporter ${ }^{+}$cells coexpressed LeX, although the precise proportion was difficult to quantify given the diffuse nature of LeX staining (Fig. 8 B). Interestingly, many reporter ${ }^{+}$cells in the subependymal layer also expressed the phosphorylated form of the astroglial transcription factor signal transducer and activator of transcription 3 (STAT3) (Fig. 8C). STAT3 acts downstream from the astrocyte differentiation factors LIF (leukemia inhibitory factor) and CNTF (ciliary neurotrophic factor) (Bonni et al., 1998; Nakashima et al., 1999), factors that have been implicated in NSC self-renewal (Shimazaki et al., 2001).

Because the NSCs of the SVZ continually generate new neurons for the $\mathrm{OB}$ in mature mammals, we examined the fate of the reporter ${ }^{+}$lineage in the OB. Both at $\mathrm{P} 35$ and at P42, a large number of report$\mathrm{er}^{+}$cells were visible in the OB (Figs. $8 E, F$, $9 B$; supplemental Fig. $4 J$, available at www. jneurosci.org as supplemental material), of which $59 \%$ were $\mathrm{NeuN}^{+}$neurons, $27 \%$ were astrocytes, and 3\% were oligodendrocytes (Table 2). Because reporter ${ }^{+}$cells were virtually absent in the OB at P8 (supplemental Table 1, available at www. jneurosci.org as supplemental material), these P35 reporter ${ }^{+}$cells most likely migrated to the OB from the SVZ, as opposed to deriving from a GCE-targeted resident population of neural precursors in the OB.

In summary, the long-term fate of $\mathrm{GFAP}^{+}$cells targeted by Cre recombination at $\mathrm{P} 5$ includes $\sim 40 \%$ of dividing neural progenitors and $60 \%$ astroglial cells that reside in the SVZ (Table 2). These cells are a likely source for targeted cells that mature into neurons and glia in the $\mathrm{OB}$ and other regions of the brain. These data imply that the astroglial cell population originally targeted at P5 includes a sizeable number of self-regenerating NSCs that persist into early adulthood.

A large proportion of newly generated cells in the DG and OB derives from the GCE-tagged astroglial lineage

The astroglial stem cells that we prospectively labeled at P5 may not be the only source of NSCs in the postnatal brain: nonastrocytic cell lineages may, in principle, contribute to the NSC population. To understand whether early postnatal GFAP ${ }^{+}$cells are a major or a minor component of the overall NSC population, we assessed to what extent the early postnatal astroglial lineage contributes to overall cell genesis in the early postnatal brain. If these early postnatal $\mathrm{GFAP}^{+}$cells represent an important source of $\boldsymbol{F}, 12.5 \mu \mathrm{m}$.

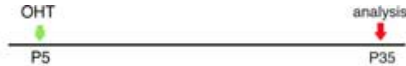

merged

NeuN \& GFP
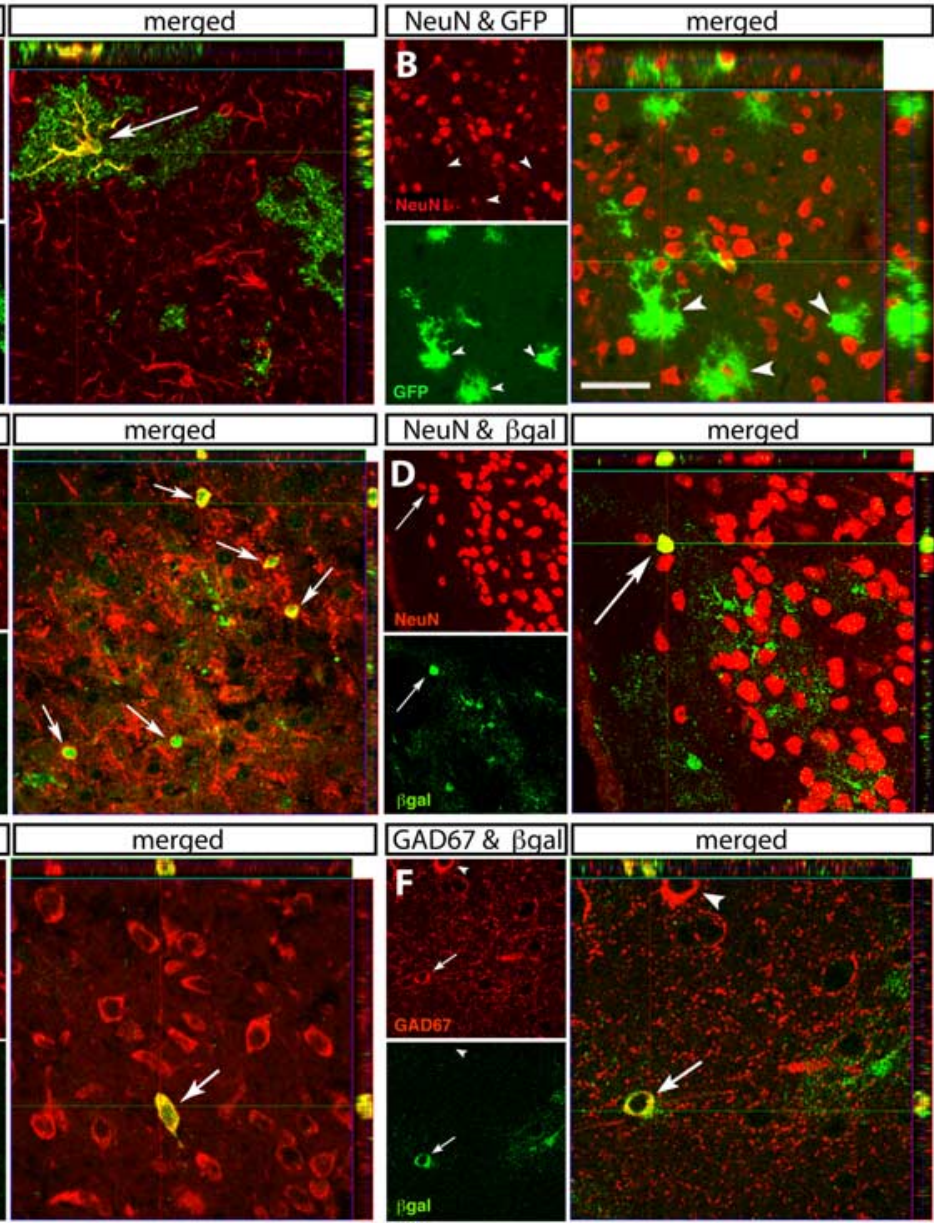

Figure 6. Long-term fate of targeted astroglial cells in the cerebral cortex. Immunocytochemical characterization of reportericated on top. Each set of three confocal images illustrates the following: on the upper left, a sagittal section immunostained , NeuN $(\boldsymbol{B}, \boldsymbol{D}), \operatorname{Rip}(\boldsymbol{C}), \mathrm{Hu}(\boldsymbol{E})$, and GAD67 $(\boldsymbol{F})$; underneath, the same section immunostained for the reporter gene;

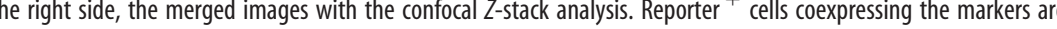
indicated by arrows, and reporter ${ }^{+}$cells negative for the markers are indicated by arrowheads. Scale bars: $\boldsymbol{B}, \boldsymbol{D}, 20 \mu \mathrm{m} ; \boldsymbol{A}, \boldsymbol{C}, \boldsymbol{E}$

NSCs, they should be the ancestors for a large portion of the neuronal progenitors, neurons and glia that are generated at this particular time in development. To answer this question, GCE; R26R double-transgenic pups were injected with OHT at P2-P6 to mark astroglial cells with the $\beta$ gal reporter and the same mice received a BrdU injection at $\mathrm{P} 7$ to label proliferating cells. After a 15 or $35 \mathrm{~d}$ survival period, cells that became postmitotic in the two to three cell cycles immediately after the BrdU injection (P7P9) were identified by BrdU immunostaining and the proportion of these cells also expressing $\beta$ gal was assessed in the DG, the OB, and the neocortex. At P22, $15 \mathrm{~d}$ after BrdU incorporation, $56.4 \pm$ $3.3 \%$ (mean $\pm \mathrm{SEM}$ ) of the BrdU ${ }^{+}$cells in the DG were immunoreactive for $\beta$ gal; similarly, $23.9 \pm 1.3 \%$ (mean \pm SEM) of the $\mathrm{BrdU}^{+}$cells in the OB were $\beta \mathrm{gal}^{+}(N=3)$ (Fig. 9A,B,D). These proportions increased at $\mathrm{P} 42$, when $67.2 \pm 0.7 \%$ (mean \pm SEM) of the $\mathrm{BrdU}^{+}$cells in the DG were $\beta \mathrm{gal}^{+}$, and $35.4 \pm 2.8 \%$ $($ mean $\pm \mathrm{SEM})$ of the $\mathrm{BrdU}^{+}$cells in the $\mathrm{OB}$ were $\beta \mathrm{gal}^{+}$. Furthermore, $>70 \%$ of these $\mathrm{BrdU}^{+} / \beta \mathrm{gal}^{+}$cells were stained for $\mathrm{NeuN}$ and thus appeared to be neurons (Fig. 9E-H, E-L), whereas a small proportion of these $\mathrm{BrdU}^{+} / \beta \mathrm{gal}^{+}$cells were 

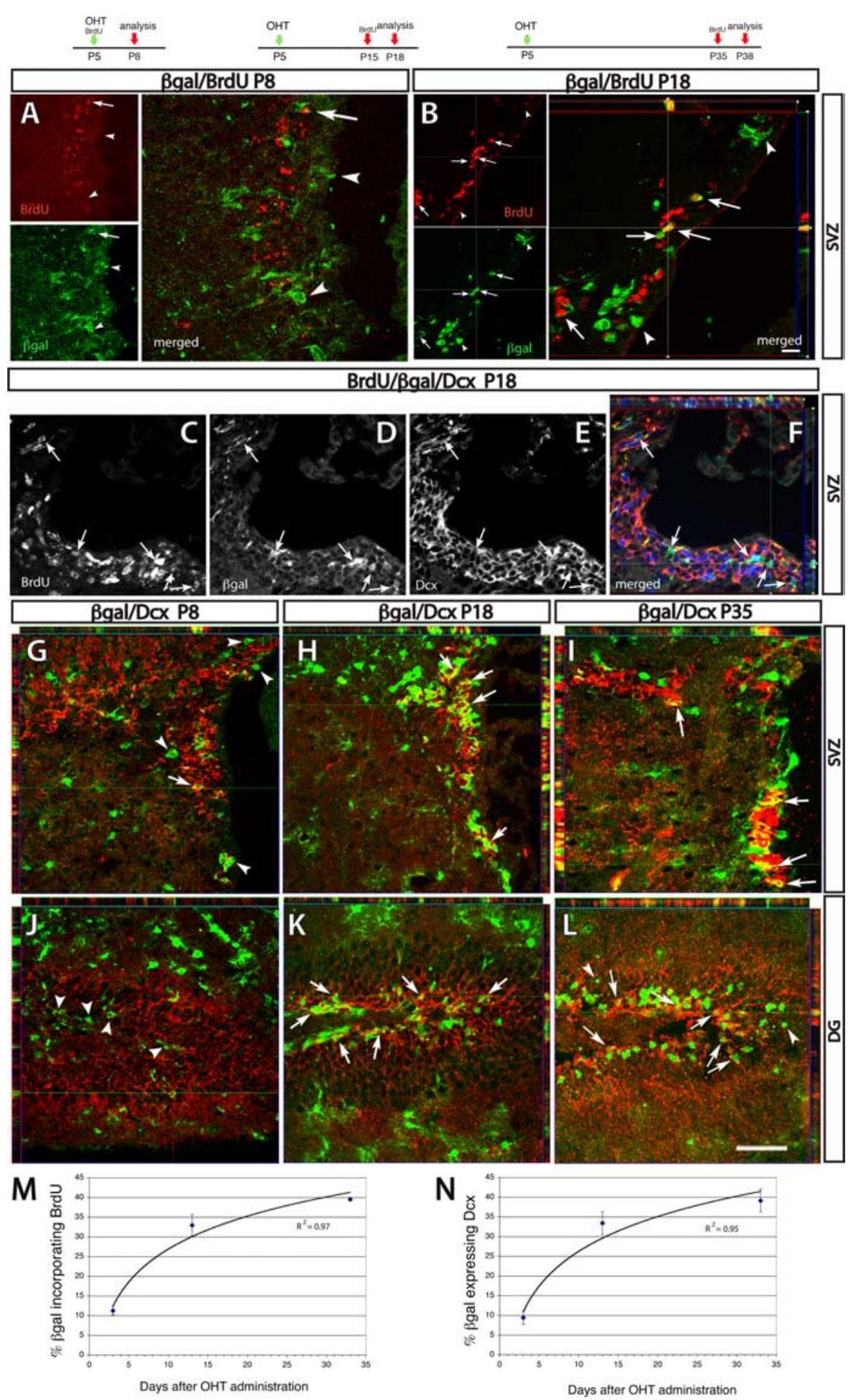

Figure 7. Cre-targeted astroglial cells generate rapidly dividing neural progenitors. GCE;R26R double transgenic mice were killed at either $\mathrm{P} 8, \mathrm{P} 18$, or $\mathrm{P} 38$ after $\mathrm{OHT}$ injections at $\mathrm{P} 5$; $\mathrm{BrdU}$ was injected $3 \mathrm{~d}$ before harvest as diagrammed. $\boldsymbol{A}, \boldsymbol{B}, \beta \mathrm{gal} / \mathrm{BrdU}$ double immunostaining at $P 8(\boldsymbol{A})$ and $P 18(\boldsymbol{B})$ in the SVZ. $\boldsymbol{C}-\boldsymbol{F}, \beta$ gal/BrdU/Dcx triple immunostaining in the SVZ at $P 18$, showing $\operatorname{BrdU}(\boldsymbol{C}), \beta \mathrm{gal}(\boldsymbol{D}), \operatorname{Dcx}(\boldsymbol{E})$ with merged images in $\boldsymbol{F}$ showing BrdU in blue, $\beta$ gal in green, and $D c x$ in red. $G-\boldsymbol{L}, \beta \mathrm{gal} / \mathrm{Dcx}$ in the SVZ $(\mathbf{G}-\boldsymbol{I})$ or $D G(\boldsymbol{J}-\boldsymbol{L})$. Reporter ${ }^{+}$cells coexpressing the markers are indicated by arrows, and reporter ${ }^{+}$cells negative for the markers are indicated by arrowheads. Images are obtained via confocal or ApoTome imaging. $M, N$, Graphs showing the proportion of reporter ${ }^{+}$cells that are $\mathrm{BrdU}^{+}(\boldsymbol{M})$ or $\mathrm{Dcx}{ }^{+}(\boldsymbol{N})$ in the SVZ across age (the curve is a logarithmic fit to the data; $N=3$ mice per time point). Error bars indicate SEM. Scale bars: (in $\boldsymbol{B}) \boldsymbol{B}, 10 \mu \mathrm{m} ; \boldsymbol{C}-\boldsymbol{F}, 15 \mu \mathrm{m}$; (in $\boldsymbol{L}) \boldsymbol{A}, \boldsymbol{I}, \boldsymbol{K}, 20 \mu \mathrm{m} ; \boldsymbol{G}, \boldsymbol{H}, \boldsymbol{J}, \boldsymbol{L}, 32 \mu \mathrm{m}$.

immunoreactive for GFAP in both the DG and the OB (data not shown). In contrast, no $\mathrm{BrdU}^{+} / \beta \mathrm{gal}^{+}$cells were positive for oligodendrocyte markers, likely because of the fact that most oligodendrocytes become postmitotic at later stages of development.
In the cerebral cortex, $38.0 \pm 6.6 \%$ of $\mathrm{BrdU}^{+}$cells colocalized $\beta$ gal immunoreactivity at P22, and, as opposed to the DG and $\mathrm{OB}$, most of them were $\mathrm{GFAP}^{+}$multipolar astrocytes (Fig. 9C) (data not shown). Together, these data show that a surprisingly large proportion of neurons generated in the early postnatal period in the $D G$ and $O B$ were the offspring of astroglial cells; this proportion is almost certainly higher considering that Cre recombination of the R26R reporter gene is not efficient enough to tag all $\mathrm{GFAP}^{+}$cells. Additionally, the data suggest that the early postnatal astroglia cell lineage contributes equally well to cortical astrocytes as it does to neurogenic NSCs.

\section{Discussion}

In this study, we used an inducible Cre recombination paradigm to tag early postnatal $\mathrm{GFAP}^{+}$cells with reporter genes to study their lineage. Our results demonstrate that these $\mathrm{GFAP}^{+}$cells exhibit properties of NSCs, namely, they give rise to proliferative neural precursors and eventually to differentiated neurons, astrocytes, and oligodendrocytes in the olfactory bulb, hippocampus, and cerebral cortex (for a diagrammatic model, see supplemental Fig. 5, available at www. jneurosci.org as supplemental material).

In double-transgenic mice harboring the GCE construct and either the Z/eG or R26R Cre reporter genes, tagged cells were characterized by mature or immature astroglial phenotypes $3 \mathrm{~d}$ after recombination. OHT levels were undetectable at this time point, suggesting that reporter expression closely reflected the complete cellular pattern of Cre recombinase activity.

As expected, the GCE transgene targeted recombination to radial glial cells when induced during embryogenesis, consistent with previous findings using the hGFAPCre line (Malatesta et al., 2003; Ohkubo et al., 2004; Casper and McCarthy, 2006), whereas during the first postnatal week, GCE targeted recombination to $\mathrm{GFAP}^{+} / \mathrm{RC}^{+}$astroglial cells of various morphologies, but not in neurons or oligodendrocytes (Table 1). In the P8 SVZ, hippocampus, and cortex, nearly all reporter ${ }^{+}$cells expressed LeX, an antigen also expressed by embryonic and adult NSCs (Capela and Temple, 2002) and the great majority were immunoreactive for $\mathrm{GFAP}^{+}$and RC1, yet in each area we observed a small population (10-20\%) of unlabeled cells. One likely explanation for this phenomenon is that these GCE targeted cells are astroglia that express low levels of GFAP protein. It is known that GFAP expression varies greatly among astrocytes (Gotz and Steindler, 
2003) and that hGFAP promoter activity may precede detectable levels of GFAP mRNA and protein by several days (Brenner and Messing, 1996). Alternatively, the unlabeled population may represent undifferentiated NSCs that have GFAP promoter activity but are undetectable by the markers used in this study. Furthermore, only a subset of all GFAP ${ }^{+}$cells demonstrated recombination of reporter genes, despite OHT doses for as many as 5 consecutive days. Although one possible reason is that not all astroglial cells are actively transcribing GFAP at the time of tamoxifen injections, another likely explanation is that the $\mathrm{R} 26 \mathrm{R}$ and the $\mathrm{Z} / \mathrm{eG}$ reporter lines underestimate the number of astrocytes that undergo Cre recombination (Casper and McCarthy, 2006).

In most gray and white matter regions, tagged cells resembled typical parenchymal astrocytes, whereas in the SVZ reporter-tagged cells were characterized by an immature morphology, with a round soma and few short processes, morphologically similar to the branched " $\mathrm{B}$ " cells described by Doetsch et al. (1999). Over $60 \%$ of reporter ${ }^{+}$cells in the SVZ expressed GFAP and LeX, antigens expressed by cells endowed with stem cell properties (Capela and Temple, 2002). Only a small fraction of the Cre-targeted cells were proliferative $3 \mathrm{~d}$ after recombination; however, in time, these cells generated a relatively large number of dividing precursors in neurogenic regions. Thirty days after tamoxifen induction, the proportion of reporter-tagged cells that incorporated BrdU in the SVZ was 40\% and a similar proportion expressed markers for young neurons (Dcx, PSA-NCAM). At this time, reporter ${ }^{+}$cells also included immature oligodendrocyte progenitors $\left(\right.$ Mash $\left.1^{+}, \mathrm{NG}^{+}\right)$. In agreement with previous evidence that neuronal progenitors proliferate in the SVZ/RMS (rostral migratory stream) (Luskin, 1993), reporter ${ }^{+} / \mathrm{Dcx}^{+}$cells were actively proliferating in these regions (Fig. $7 C-F$ ). The data suggest that postnatal $\mathrm{GFAP}^{+}$cells are the ancestors for dividing neuronal precursors in young adult mice. The relatively slow time course of BrdU incorporation into astroglial lineage cells noted here argues in favor of distinct kinetics of cell division for GFAP ${ }^{+}$NSCs and neuronal progenitors. Whereas the latter divide with a cell cycle of $\sim 13 \mathrm{~h}$, the former have a cell cycle estimated to be in the order of 2-3 weeks; hence, 15-20 d are likely to be required for NSCs to complete cell division and give rise to mitotic progenitors (Morshead et al., 1994; Zheng et al., 2004).

Progenitors of $\mathrm{GFAP}^{+}$ancestry were able to reach full maturity, as corroborated by the large number of reporter ${ }^{+}$astrocytes, neurons, and oligodendrocytes in the hippocampus, $\mathrm{OB}$, and cerebral cortex. However, their relative proportion varied from region to region. For example, in the $\mathrm{OB}$, tagged cells generated neurons, astrocytes, and oligodendrocytes 4 weeks after recombination. However, GCE-tagged cells generated mostly neurons in the DG, only astrocytes in the hippocampal pyramidal layer, and astrocytes as well as oligodendrocytes in the hippocampal and cerebellar WM (Table 2). In the DG, the range of neuronal phenotypes generated from $\mathrm{GFAP}^{+}$precursors encompassed all of the previously described stages of maturation of hippocampal granule cells (Esposito et al., 2005): some were aspiny, bearing simple dendrites (class B), whereas others had longer, highly branched spiny dendrites and axons in the hilus (class C or D). Our results confirm and extend previous data showing that DG granule neurons are an offspring of astroglial progenitors (Morshead et al., 2003; Garcia et al., 2004).

In the cerebral cortex, $\mathrm{GFAP}^{+}$precursors gave rise to astrocytes, oligodendrocytes, and a small number of neurons; some of these neurons were GABAergic. Despite the fact that these neurons represented $<1 \%$ of the reporter ${ }^{+}$cells in this region, their presence is particularly exciting because it offers evidence of neurogenesis from the astroglial lineage in the neonatal mouse cerebral cortex. Although the occurrence of cortical neurogenesis in adult mammals is still under debate (Gould et al., 1999; Kornack and Rakic, 2001), we observed this phenomenon in juvenile mice (Fagel et al., 2006). Furthermore, neonatal cortical astrocytes are 

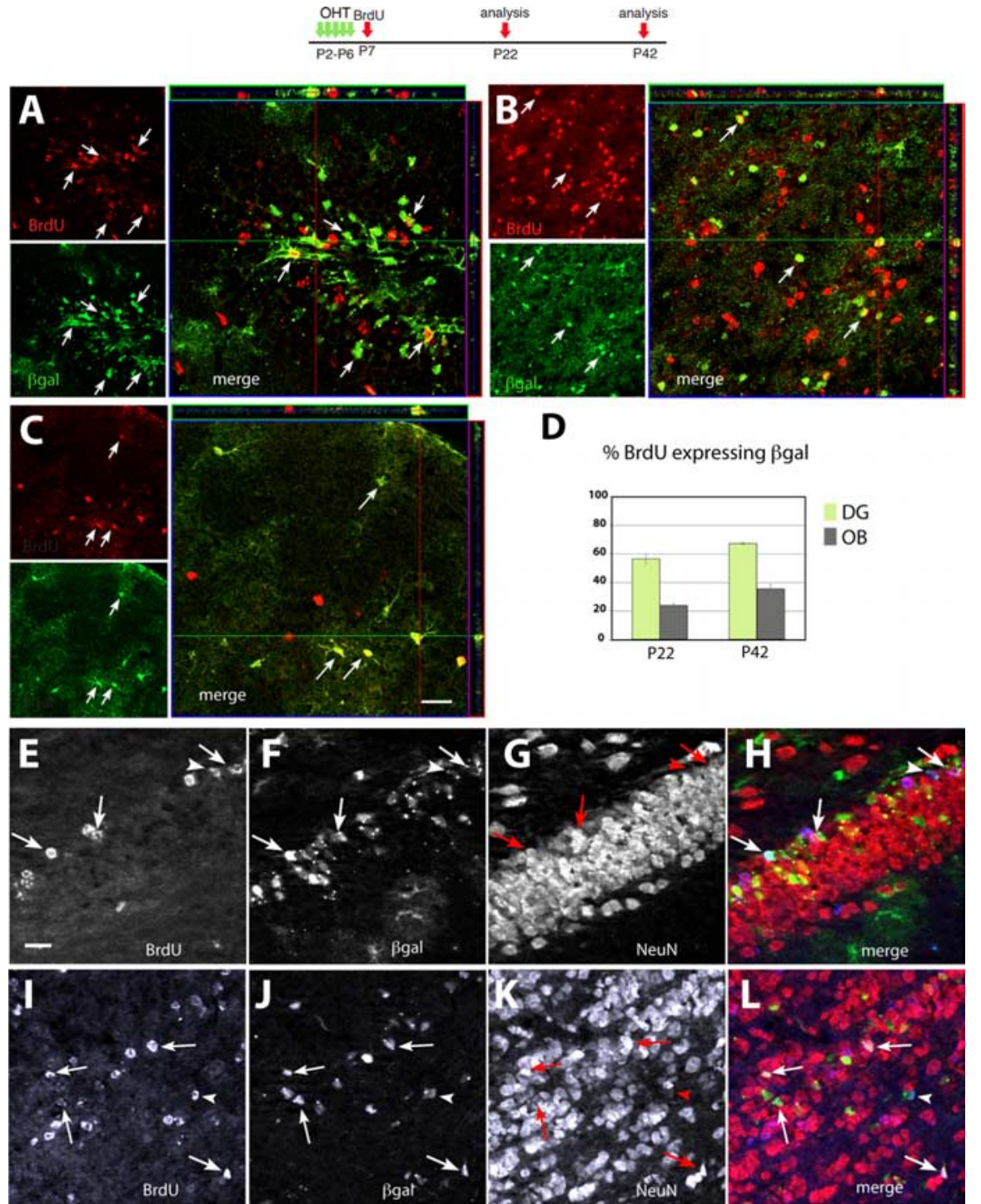

Figure 9. A high proportion of newly generated cells in the early postnatal period are GCE progeny. Characterization of reporter ${ }^{+}$cells in P22 and P42 mice after daily OHT injections at P2-P6 and one BrdU injection at P7.A-C, P22; E-L, P42.A, E-H, DG. $\boldsymbol{B}, \mathbf{I}-\mathbf{L}, 0 \mathrm{~B}$. C, Cerebral cortex. $\boldsymbol{A}-\boldsymbol{C}$, Sets of confocal images representing on the upper left, a sagittal section immunostained with $\mathrm{BrdU}$ in red; underneath, the same section stained for $\beta$ gal in green; and on the right side, the merged images and Z-stack analyses. D, Graph showing the proportion of BrdU ${ }^{+}$cells that are reporter ${ }^{+}$in the DG (green bars) or OB (gray bars) at each age $(N=3$ mice per time point). Error bars indicate SEM. $\boldsymbol{E}-\boldsymbol{L}$, ApoTome imaging of triple-immunostained sections showing $\operatorname{BrdU}(\boldsymbol{E}$, $\boldsymbol{I}), \beta \mathrm{gal}(\boldsymbol{F}, \boldsymbol{J})$, and $\operatorname{NeuN}(\boldsymbol{G}, \boldsymbol{K})$ with merged images in $\boldsymbol{H}$ and $\boldsymbol{L}$ showing BrdU in blue, $\beta$ gal in green, and NeuN in red. Scale bars, $20 \mu \mathrm{m}$.

able to generate neurons in vitro (Laywell et al., 2000). Equally surprising is the observation that $14 \%$ of reporter ${ }^{+}$cells in cortex acquire an oligodendrocyte fate. Recent studies have proposed that $\mathrm{NG}^{+}$cells, previously thought to exclusively generate oligodendrocytes, may also generate neurons in the hippocampus (Aguirre et al., 2004). Because NG2 ${ }^{+}$cells can be progeny of $\mathrm{GFAP}^{+}$precursors (supplemental Fig. 4, available at www.jneurosci.org as supplemental material), a likely scenario reconciling these findings is that astroglial lineage cells generate $\mathrm{NG}^{+}$progenitors in the early postnatal period, which in turn develop into neurons as well as oligodendrocytes.

The colocalization of the reporter genes with neuronal and oligodendrocyte markers at P35 cannot be attributed to initial misexpression of the $h$ GFAP transgenic promoter in neurons or oligodendrocytes. Hence, $\mathrm{GFAP}^{+}$cells include precursors that
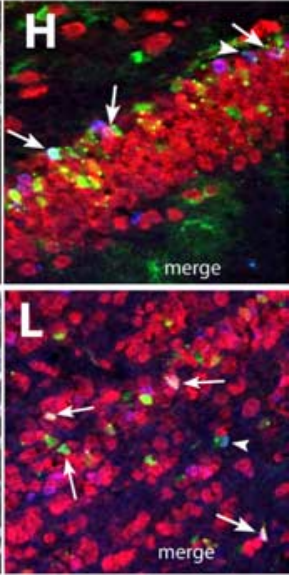

downregulate GFAP expression, acquire neuronal and oligodendroglial precursor cell fates, and eventually give rise to neurons, astrocytes, and oligodendrocytes throughout the forebrain. However, our data do not reveal whether the same progenitor cells that can generate neurons can also give rise to astrocytes and/or oligodendrocytes.

Not all progenitors and newly generated cells are reporter ${ }^{+}$, raising the important question of whether all postnatal NSCs share this GFAP ${ }^{+}$ancestry. We cannot settle this question, because we are not able to mark with reporter genes all $\mathrm{GFAP}^{+}$cells in the perinatal period. Because of this limitation, not all NSCs are likely to be targeted even if they were all derived from $\mathrm{GFAP}^{+}$precursors. The underlying reason for this mosaicism is most likely inefficiency in the nuclear targeting of the Cre fusion protein and subsequent excision at loxP sites attributable in part to the short half-life of 4-OHT. Another likely explanation is variable expression of the reporter genes used in this study. Despite these shortcomings, it is surprising that GCE-targeted cells appeared to contribute a substantial proportion of the newly generated cells for the DG and the OB. This was demonstrated by an experiment in which $\mathrm{GFAP}^{+}$cells were tagged via $\mathrm{OHT}$ injections at $\mathrm{P} 2-\mathrm{P} 6$ and $\mathrm{BrdU}$ was injected at P7. Cells that retained detectable BrdU labeling after a period of $2-5$ weeks are those that became postmitotic in the two to three cell cycles after BrdU injection. Confirming this, $>70 \%$ of the $\mathrm{BrdU}^{+}$cells expressed NeuN in the DG (Fig. 9E-H). Among these $\mathrm{BrdU}^{+}$cells, 35 and $67 \%$ were $\beta \mathrm{gal}^{+}$in the OB and DG, respectively, and thus the offspring of $\mathrm{GFAP}^{+}$cells. Together, the data strongly suggest that early postnatal $\mathrm{GFAP}^{+}$cells give rise to a substantial proportion of the NSCs in the mature brain. Similarly, it was recently shown that $\mathrm{GFAP}^{+}$astrocytes targeted in adult GLAST-GeERT2 mice gave rise to $50 \%$ of all OB interneurons after 4 months (Mori et al., 2006). However, because of the incomplete targeting as discussed above, we cannot completely rule out that there is a separate lineage for NSCs (e.g., NG2-expressing progenitors) that does not derive from $\mathrm{GFAP}^{+}$cells.

In conclusion, genetic fate mapping evidence presented here indicates that the GFAP ${ }^{+}$cells tagged via the GCE transgene near the end of the first postnatal week include NSCs that seed the postnatal neurogenic zones (supplemental Fig. 5, available at www.jneurosci.org as supplemental material). Our strategy also reveals that early postnatal $\mathrm{GFAP}^{+}$cells undergo markedly divergent fates in different regions of the developing brain. In the hippocampus and $\mathrm{OB}, \mathrm{GFAP}^{+}$cells generate mostly neurons, but also astrocytes and oligodendrocytes. Conversely, in the cerebral cortex and in WM, the majority of $\mathrm{GFAP}^{+}$cells differentiated 
into astrocytes and oligodendrocytes. A significant question raised by these experiments is whether these differing fates depend on intrinsic characteristics of astroglia, or whether they are signaled by the local environment. Future experiments will explore to what extent perturbations of the local environment influence these events.

\section{References}

Aguirre A, Gallo V (2004) Postnatal neurogenesis and gliogenesis in the olfactory bulb from NG2-expressing progenitors of the subventricular zone. J Neurosci 24:10530-10541.

Aguirre AA, Chittajallu R, Belachew S, Gallo V (2004) NG2-expressing cells in the subventricular zone are type C-like cells and contribute to interneuron generation in the postnatal hippocampus. J Cell Biol 165:575-589.

Anthony TE, Klein C, Fishell G, Heintz N (2004) Radial glia serve as neuronal progenitors in all regions of the central nervous system. Neuron 41:881-890.

Bonni A, Sun Y, Nadal-Vicens M, Bhatt A, Frank DA, Rozovsky I, Stahl N, Yancopoulos GD, Greenberg ME (1998) Regulation of gliogenesis in the central nervous system by the JAK-STAT signaling pathway. Science 278:477-483.

Brenner M (1994) Structure and transcriptional regulation of the GFAP gene. Brain Pathol 4:245-257.

Brenner M, Messing A (1996) GFAP transgenic mice. Methods 10:351-364.

Brenner M, Kisseberth WC, Su Y, Besnard F, Messing A (1994) GFAP promoter directs astrocyte-specific expression in transgenic mice. J Neurosci 14:1030-1037.

Bull ND, Bartlett PF (2005) The adult mouse hippocampal progenitor is neurogenic but not a stem cell. J Neurosci 25:10815-10821.

Capela A, Temple S (2002) LeX/ssea-1 is expressed by adult mouse CNS stem cells, identifying them as nonependymal. Neuron 35:865-875.

Casper KB, McCarthy KD (2006) GFAP-positive progenitor cells produce neurons and oligodendrocytes throughout the CNS. Mol Cell Neurosci 31:676-684.

Doetsch F, Garcia-Verdugo JM, Alvarez-Buylla A (1997) Cellular composition and three-dimensional organization of the subventricular germinal zone in the adult mammalian brain. J Neurosci 17:5046-5061.

Doetsch F, Caille I, Lim DA, Garcia-Verdugo JM, Alvarez-Buylla A (1999) Subventricular zone astrocytes are neural stem cells in the adult mammalian brain. Cell 97:703-716.

Dyer CA, Hickey WF, Geisert Jr EE (1991) Myelin/oligodendrocyte-specific protein: a novel surface membrane protein that associates with microtubules. J Neurosci Res 28:607-613.

Edwards MA, Yamamoto M, Caviness Jr VS (1990) Organization of radial glia and related cells in the developing murine CNS. An analysis based upon a new monoclonal antibody marker. Neuroscience 36:121-144.

Englund C, Fink A, Lau C, Pham D, Daza RA, Bulfone A, Kowalczyk T, Hevner RF (2005) Pax6, Tbr2, and Tbr1 are expressed sequentially by radial glia, intermediate progenitor cells, and postmitotic neurons in developing neocortex. J Neurosci 25:247-251.

Esposito MS, Piatti VC, Laplagne DA, Morgenstern NA, Ferrari CC, Pitossi FJ, Schinder AF (2005) Neuronal differentiation in the adult hippocampus recapitulates embryonic development. J Neurosci 25:10074-10086.

Fagel DM, Ganat Y, Silbereis J, Ebbitt T, Stewart W, Zhang H, Ment LR, Vaccarino FM (2006) Cortical neurogenesis enhanced by chronic perinatal hypoxia. Exp Neurol 199:77-91.

Feil R, Brochard J, Mascrez B, LeMeur M, Metzger D, Chambon P (1996) Ligand-activated site-specific recombination in mice. Proc Natl Acad Sci USA 93:10887-10890.

Gadisseux JF, Evrard P, Mission JP, Caviness Jr VS (1992) Dynamic changes in the density of radial glial fibers of the developing murine cerebral wall: a quantitative immunohistological analysis. J Comp Neurol 322:246-254.

Gal JS, Morozov YM, Ayoub AE, Chatterjee M, Rakic P, Haydar TF (2006) Molecular and morphological heterogeneity of neural precursors in the mouse neocortical proliferative zones. J Neurosci 26:1045-1056.

Ganat Y, Soni S, Chacon M, Schwartz ML, Vaccarino FM (2002) Chronic hypoxia up-regulates fibroblast growth factor ligands in the perinatal brain and induces fibroblast growth factor-responsive radial glial cells in the sub-ependymal zone. Neuroscience 112:977-991.

Garcia AD, Doan NB, Imura T, Bush TG, Sofroniew MV (2004) GFAP- expressing progenitors are the principal source of constitutive neurogenesis in adult mouse forebrain. Nat Neurosci 7:1233-1241.

Gotz M, Steindler D (2003) To be glial or not-how glial are the precursors of neurons in development and adulthood? Glia 43:1-3.

Gould E, Reeves AJ, Graziano MSA, Gross CG (1999) Neurogenesis in the neocortex of adult primates. Science 286:548-552.

Gregg C, Weiss S (2003) Generation of functional radial glial cells by embryonic and adult forebrain neural stem cells. J Neurosci 23:11587-11601.

Indra AK, Warot X, Brocard J, Bornert JM, Xiao JH, Chambon P, Metzger D (1999) Temporally-controlled site-specific mutagenesis in the basal layer of the epidermis: comparison of the recombinase activity of the tamoxifen-inducible Cre-ER(T) and Cre-ER(T2) recombinases. Nucleic Acids Res 27:4324-4327.

Kornack DR, Rakic P (2001) Cell proliferation without neurogenesis in adult primate neocortex. Science 294:2127-2130.

Kriegstein AR, Gotz M (2003) Radial glia diversity: a matter of cell fate. Glia 43:37-43.

Laywell E, Rakic P, Kukekov VG, Holland EC, Steindler DA (2000) Identification of a multipotent astrocytic stem cell in the immature and adult mouse brain. Proc Natl Acad Sci USA 97:13883-13888.

Leone DP, Genoud S, Atanasoski S, Grausenburger R, Berger P, Metzger D, Macklin WB, Chambon P, Suter U (2003) Tamoxifen-inducible gliaspecific Cre mice for somatic mutagenesis in oligodendrocytes and Schwann cells. Mol Cell Neurosci 22:430-440.

Liu Y, Wu Y, Lee JC, Xue H, Pevny LH, Kaprielian Z, Rao MS (2002) Oligodendrocyte and astrocyte development in rodents: an in situ and immunohistological analysis during embryonic development. Glia 40:25-43.

Lois C, Alvarez-Buylla A (1993) Proliferating subventricular zone cells in the adult mammalian forebrain can differentiate into neurons and glia. Proc Natl Acad Sci USA 90:2074-2077.

Luskin MB (1993) Restricted proliferation and migration of postnatally generated neurons derived from the forebrain ventricular zone. Neuron 11:173-189.

Malatesta P, Harfuss E, Gotz M (2000) Isolation of radial glial cells by fluorescent-activated cell sorting reveals a neuronal lineage. Development 127:5253-5263.

Malatesta P, Hack MA, Hartfuss E, Kettenmann H, Klinkert W, Kirchnoff F, Gotz M (2003) Neuronal or glial progeny: regional differences in radial glia fate. Neuron 37:751-764.

Marshall CA, Suzuki SO, Goldman JE (2003) Gliogenic and neurogenic progenitors of the subventricular zone: who are they, where did they come from, and where are they going? Glia 43:52-61.

Merkle FT, Tramontin AD, Garcia-Verdugo JM, Alvarez-Buylla A (2004) Radial glia give rise to adult neural stem cells in the subventricular zone. Proc Natl Acad Sci USA 101:17528-17532.

Metzger D, Clifford J, Chiba H, Chambon P (1995) Conditional sitespecific recombination in mammalian cells using a ligand-dependent chimeric Cre recombinase. Proc Natl Acad Sci USA 92:6991-6995.

Misson JP, Edwards MA, Yamamoto M, Caviness Jr VS (1988) Identification of radial glial cells within the developing murine central nervous system: studies based upon a new immunohistochemical marker. Brain Res Dev Brain Res 44:95-108.

Mori T, Tanaka K, Buffo A, Wurst W, Kuhn R, Gotz M (2006) Inducible gene deletion in astroglia and radial glia-a valuable tool for functional and lineage analysis. Glia 54:21-34.

Morshead CM, Reynolds BA, Craig CG, McBurney MW, Staines WA, Morassutti D, Weiss S, van der Kooy D (1994) Neural stem cells in the adult mammalian forebrain: a relatively quiescent subpopulation of subependimal cells. Neuron 13:1071-1082.

Morshead CM, Garcia AD, Sofroniew MV, van Der Kooy D (2003) The ablation of glial fibrillary acidic protein-positive cells from the adult central nervous system results in the loss of forebrain neural stem cells but not retinal stem cells. Eur J Neurosci 18:76-84.

Nakashima K, Yanagisawa M, Arakawa H, Kimura N, Hisatsune T, Kawabata M, Miyazono K, Taga T (1999) Synergistic signaling in fetal brain by STAT3-Smad1 complex bridged by p300. Science 284:479-482.

Noctor SC, Flint AC, Weissman TA, Dammerman RS, Kriegstein AR (2001) Neurons derived from radial glial cells establish radial units in neocortex. Nature 409:714-720.

Novak A, Guo C, Yang W, Nagy A, Lobe CG (2000) Z/EG, a double reporter 
mouse line that expresses enhanced green fluorescent protein upon Cremediated excision. Genesis 28:147-155.

Ohkubo Y, Uchida AO, Shin D, Partanen J, Vaccarino FM (2004) Fibroblast growth factor receptor 1 is required for the proliferation of hippocampal progenitor cells and for hippocampal growth in mouse. J Neurosci 24:6057-6069.

Parras CM, Galli R, Britz O, Soares S, Galichet C, Battiste J, Johnson JE, Nakafuku M, Vescovi A, Guillemot F (2004) Mash1 specifies neurons and oligodendrocytes in the postnatal brain. EMBO J 23:4495-4505.

Pixley SKR, de Vellis J (1984) Transition between immature glia and mature astrocytes studied with a monoclonal antibody to vimentin. Brain Res Dev Brain Res 15:201-209.

Sauer B (1998) Inducible gene targeting in mice using the Cre/lox system. Methods 14:381-392.

Schmechel SE, Rakic P (1979) A Golgi study of radial glial cells in developing monkey telencephalon: morphogenesis and transformation into astrocytes. Anat Embryol 156:115-152.

Seaberg RM, van der Kooy D (2002) Adult rodent neurogenic regions: the ventricular subependyma contains neural stem cells, but the dentate gyrus contains restricted progenitors. J Neurosci 22:1784-1793.
Seri B, Garcia-Verdugo JM, McEwen BS, Alvarez-Buylla A (2001) Astrocytes give rise to new neurons in the adult mammalian hippocampus. J Neurosci 21:7153-7160.

Shimazaki T, Shingo T, Weiss S (2001) The ciliary neurotrophic factor/leukemia inhibitory factor/gp130 receptor complex operates in the maintenance of mammalian forebrain neural stem cells. J Neurosci 21:7642-7653.

Smith KM, Ohkubo Y, Maragnoli ME, Rasin MR, Schwartz ML, Sestan N, Vaccarino FM (2006) Midline radial glia translocation and corpus callosum formation require FGF signaling. Nat Neurosci 9:787-797.

Soriano P (1999) Generalized lacZ expression with the ROSA26 Cre reporter strain. Nat Gen 21:70-71.

Zerlin M, Milosevic A, Goldman JE (2004) Glial progenitors of the neonatal subventricular zone differentiate asynchronously, leading to spatial dispersion of glial clones and to the persistence of immature glia in the adult mammalian CNS. Dev Biol 270:200-213.

Zheng W, Nowakowski RS, Vaccarino FM (2004) Fibroblast growth factor 2 is required for maintaining the neural stem cell pool in the mouse brain subventricular zone. Dev Neurosci 26:181-196. 